\title{
Hydro-climatic changes in the Niger basin and consistency of local perceptions
}

\author{
Ganiyu Titilope Oyerinde $\cdot$ Fabien C. C. Hountondji • \\ Dominik Wisser • Bernd Diekkrüger • \\ Agnide E. Lawin · Ayo J. Odofin • Abel Afouda
}

Received: 4 June 2014/ Accepted: 26 October 2014/Published online: 15 November 2014

(C) The Author(s) 2014. This article is published with open access at Springerlink.com

\begin{abstract}
Since the 1970s, the Niger basin has been characterized by hydro-climatic changes which have significant impacts on local populations. These changes are not well documented as a result of a decreasing observation network for hydro-climatic data. Indigenous peoples' knowledge has increasingly been considered an important component in addressing these data gaps. We evaluated the consistency of indigenous perceptions and adaptive responses with rainfall and river discharge observations in the Niger basin. Socioeconomic data were collected from 239 households in 30 communities across two settlements in the Niger basin. Data on historical rainfall and river discharge from 1950 to 2010 were analyzed and the consistency with local perceptions was
\end{abstract}

Editor: James D. Ford.

G. T. Oyerinde $(\bowtie)$ - F. C. C. Hountondji - A. Afouda Graduate Research Program (GRP) Climate Change and Water Resources, West African Science Service Center on Climate Change and Adapted Land Use (WASCAL), University of Abomey-Calavi, Cotonou, Benin

e-mail: ganiyuoyerinde@yahoo.com

F. C. C. Hountondji

e-mail: fabienho@yahoo.com

A. Afouda

e-mail: aafouda@yahoo.fr

F. C. C. Hountondji

Ecole Nationale Supérieure des Sciences et Techniques Agronomiques de Djougou, University of Parakou, Parakou, Benin

D. Wisser

Center for Development Research, University of Bonn,

53113 Bonn, Germany

e-mail: dwisser@uni-bonn.de assessed. Generally, there was a high agreement between observations and perceptions, but impacts of climate change in the communities were dependent on social and environmental factors that can introduce differences in perception despite identical observations. Indigenous perceptions gave good indication of the most vulnerable sectors as well as communities who also displayed the greatest willingness to combat climate change. These results suggest that integration of indigenous perceptions into climate change science, especially in data scarce regions, is highly valuable.

Keywords Regional climate change · Hydrology · Perceptions · Adaptations · Niger basin

\section{B. Diekkrüger}

Department of Geography, University of Bonn, Meckenheimer Allee 166, 53115 Bonn, Germany

e-mail: b.diekkrueger@uni-bonn.de

A. E. Lawin

Laboratory of Applied Hydrology, Faculty of Sciences and

Technology, University of Abomey-Calavi, Abomey-Calavi,

Benin

e-mail: ewaari@yahoo.fr

\author{
A. J. Odofin \\ Department of Soil Science, Federal University of Technology, \\ Minna, Nigeria \\ e-mail: odofinayo@yahoo.co.uk
}




\section{Introduction}

Climate change has significant impacts on ecosystems and societies in West Africa and adaptation to it is hindered by poorly documented historical climate trends and future projections. Historical climate trends are not properly captured in the region due to inadequate and deteriorating amount of reliable observation stations since 1980 (Ali and Lebel 2009). Satellite-based observations of precipitation have also been identified with inherent biases in the region as a result of insufficient ground-based data for calibration and validation (Sylla et al. 2013). This has led to contradictory results from climate trend studies at local and subregional scales. For instance, following the 1990s' report of the Sahelian drought (Sivakumar 1992; Le Barbé and Lebel 1997), several studies considered it either ended in the 1990s (Ozer et al. 2003), continued (Hulme 2001; L'Hote et al. 2002; Dai et al. 2004) or even was simply an artifact of changing station networks (Chappell and Agnew 2008). The recent discovery of a precipitation gradient from eastern to western Sahel (Lebel and Ali 2009) in addition to the north-south Inter Tropical Convergence Zone (ITCZ) influence on rainfall distribution is also a factor of importance for reliable hydrological predictions in West Africa.

For future conditions, no coherent projection for either decreasing or increasing precipitation emerges from global climate model (GCM) products (Druyan 2011). This lack of consensus among GCM projections was attributed to the unclear West African monsoon precipitation response to anthropogenic climate change (Biasutti and Giannini 2006; Douville et al. 2006; Giannini et al. 2008). In addition, the typical grid box of GCMs (in the range of $100-400 \mathrm{~km}$ ) is too coarse to account for land surface heterogeneities from vegetation, topography and coastlines, which are important for the physical response governing the local and regional climate change signal (Paeth et al. 2006; Rummukainen 2010). Regional Climate Models (RCM) can potentially overcome this limitation; however, Diallo et al. (2012) found mixed results in terms of RCMs improving the simulation of climate patterns compared to the driving GCMs.

These climate uncertainties exacerbate the vulnerability of West African populations both to high natural variability of climate and anticipated climatic changes in the future (Mertz et al. 2011). High population density, large growth rates and the dependence on rainfed agriculture make economies particularly vulnerable. The prominent West African average rainfall deficit of $180 \mathrm{~mm}$ in 1970s and 1980s relative to the 1950s and 1960s (Le Barbé et al. 2002) resulted in severe famine and crop failure (Ben Mohamed et al. 2002). The increase of precipitation since 1990 (Lebel and Ali 2009) aggravated the intensities of floods in the region; Yabi and Afouda (2012) reported the disruption of agricultural activities during extreme rainfall years in Benin which swept out over $24 \%$ of the state revenue from agriculture. Increases in West Africa's air temperature could further increase the vulnerability of agriculture through a yield reduction as a result of heat stress, although large discrepancies exist in yield predictions as a result of climate change in West Africa and the sign of change is uncertain (Roudier et al. 2011).

The Niger River Basin, the largest basin in the region was also identified with uncertainties and contradictory hydro-climatic information. A vivid example is the "paradox" which is an observed runoff increase in some of the basin's Sahelian catchments such as in Nakanbe (Burkina Faso), Sirba (Niger) and Mekrou (Benin) despite a decrease in rainfall (Mahe et al. 2005; Descroix et al. 2009). This was attributed to soil crusting and land degradation as a result of unsustainable land use in the basin (Amogu et al. 2010). High rainfall spatial and temporal variability in the basin has significant impacts on water resources (Oyebande and Odunuga 2010). In the past 50 years, a 10-30\% decrease in mean annual rainfall in the basin has led to a reduction of 20-60\% in river discharge (Oyebande and Odunuga 2010). Even with no change in precipitation, the availability of per capita renewable water resources in the basin is declining as a result of a large population growth; the population in the basin is expected to double from 94 million in 2005 to over 150 million by the year 2050, and competing demands have led to challenges in water allocation among different users and countries (Ogilvie et al. 2010). A sustainable management strategy is therefore needed to cope with challenges arising from increases in water demand and changes in the variability of supply in the basin.

Local communities in the Niger basin have responded to variations in water availability through the use of water harvesting, irrigation, planting of drought tolerant and early maturing crop varieties and others. Therefore, knowledge of local communities on recent climate variability $(<20$ years) and adaptation measures is very valuable, particularly in the absence of reliable local observations and projections. Several studies such as (West et al. 2008; Mertz et al. 2009; Kemausuor et al. 2011; Fosu-Mensah et al. 2012; Tambo and Abdoulaye 2012) have already displayed high consistencies between local perceptions and observations. The IPCC Summary for Policymakers (2014) also showcased that "adaptation planning and implementation at all levels of governance are contingent on societal values, objectives and risk perceptions." However, some biases are witnessed in local perceptions, which are caused by some environmental factors such as extreme droughts. Such bias was witnessed in Ethiopia where the perceived 1980s' dry years due to large-scale famine conditions were 


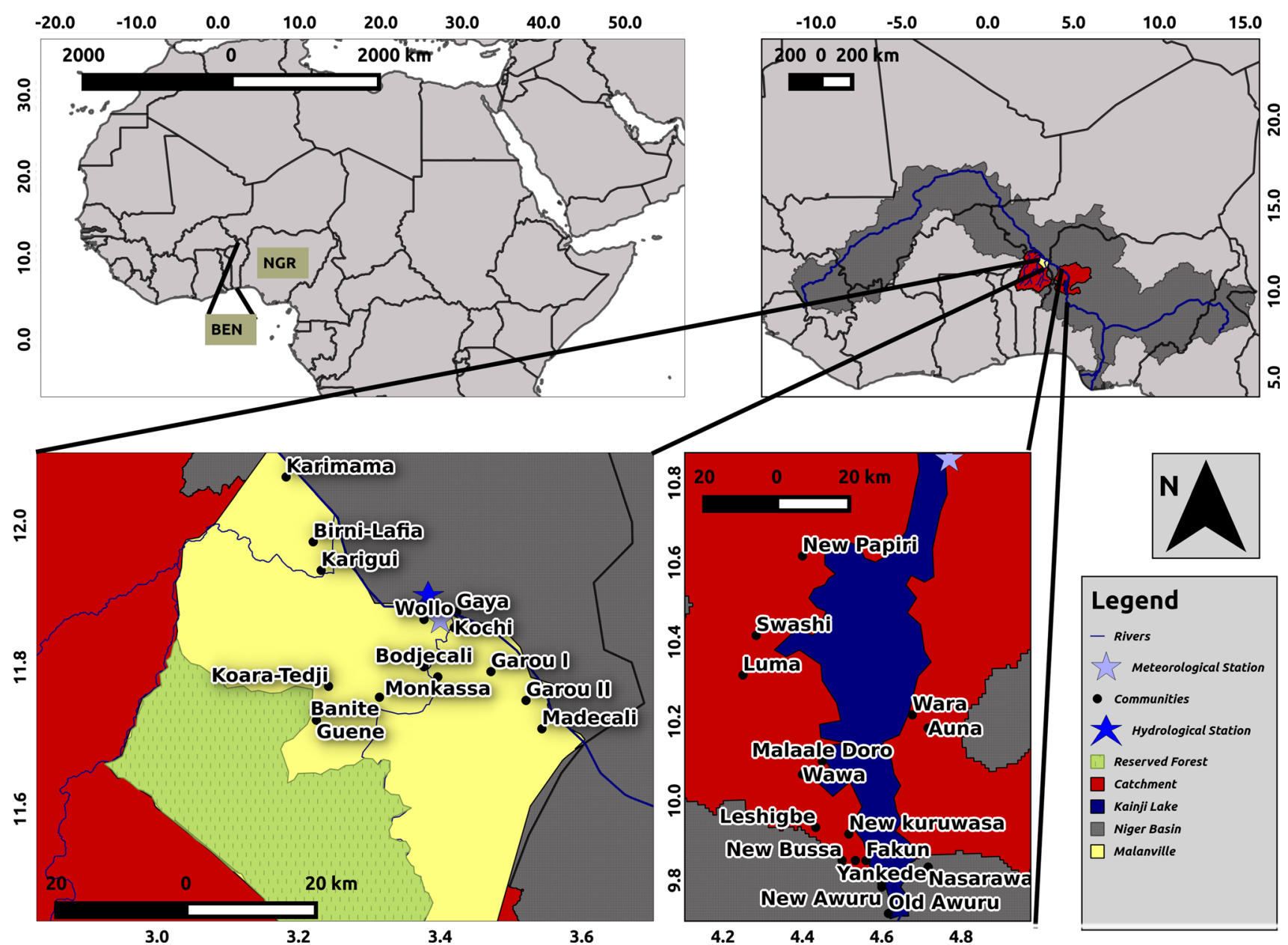

Fig. 1 Location of sampled communities in Malanville (Benin) and Kainji (Nigeria)

one of the wettest years in the region (Meze-Hausken 2004). Kalanda-Joshua et al. (2011) also reported that local perceptions are based on the ability of respondents to recall key events and are, thus, more accurate on recent climatic events $(<30$ years). This study aimed at ameliorating these challenges by evaluating consistency of local perceptions with recent observations starting from 1990; after recovery from the West African drought was witnessed in some parts of the region (Ali and Lebel 2009). We also assessed the potential of local perceptions in enhancing adaptation efforts in the Niger River Basin."

The objectives of the study were to:

- evaluate trends of precipitation, river discharge and local perceptions in Malanville (Benin) and Kainji (Nigeria) settlements along the Niger river,

- assess the agreement of local perceptions with hydroclimatic observations, and

- evaluate local adaptation mechanisms to climate change.
Data and methods

\section{Study area}

The Niger River Basin covers 2.27 million $\mathrm{km}^{2}$ (Ogilvie et al. 2010), and with 4,200 $\mathrm{km}$ in length, the Niger is the third longest river in Africa. The basin consists of 10 countries including some parts of Benin and Nigeria, where the study sites (Malanville and Kainji) are located (Fig. 1). Malanville commune (lowest administrative level in Benin) covers an area of $3,016 \mathrm{~km}^{2}$ and had a population of about 160,000 people in 2013 (INSAE 2013). It has a mean annual precipitation of about $800 \mathrm{~mm}$ (based on observations from 1950 to 2010) which is concentrated in one rainy season from mid April to mid October. During the dry season, Malanville is subject to the Sahelian northeast trade wind that comes with relatively cool and dry environmental conditions. Highest temperatures of about $46{ }^{\circ} \mathrm{C}$ are recorded in March and April, while the lowest temperatures (about $16^{\circ} \mathrm{C}$ ) are observed in December and 
Table 1 Variables of the socioeconomic survey conducted in Malanville (Benin) and Kainji (Nigeria)

\begin{tabular}{|c|c|c|}
\hline $\begin{array}{l}\text { Group of } \\
\text { variables }\end{array}$ & Variables & Description \\
\hline \multirow{3}{*}{$\begin{array}{l}\text { Hydro- } \\
\text { climatic } \\
\text { variability }\end{array}$} & Rainfall & $\begin{array}{l}\text { Observed trend of } \\
\text { precipitation }\end{array}$ \\
\hline & $\begin{array}{l}\text { Dynamics of water } \\
\text { bodies }\end{array}$ & $\begin{array}{l}\text { Observed trend of river } \\
\text { discharge }\end{array}$ \\
\hline & Climate change & $\begin{array}{l}\text { Awareness about climate } \\
\text { change and its impacts }\end{array}$ \\
\hline \multirow[t]{2}{*}{$\begin{array}{l}\text { Extreme } \\
\text { events }\end{array}$} & Flood & $\begin{array}{l}\text { Observed trend of flood } \\
\text { occurrence }\end{array}$ \\
\hline & Rainfall frequency & Frequency of rainfall \\
\hline \multirow[t]{3}{*}{$\begin{array}{l}\text { Adaptation } \\
\text { mechanism }\end{array}$} & $\begin{array}{l}\text { Soil and water } \\
\text { conservation } \\
\text { mechanism }\end{array}$ & $\begin{array}{l}\text { Local land conservation } \\
\text { techniques }\end{array}$ \\
\hline & Flood adaptation & $\begin{array}{l}\text { Management strategies for } \\
\text { ameliorating impacts of } \\
\text { floods }\end{array}$ \\
\hline & $\begin{array}{l}\text { Declining rainfall } \\
\text { adaptation }\end{array}$ & $\begin{array}{l}\text { Strategies of resilience to } \\
\text { decline in rainfall }\end{array}$ \\
\hline
\end{tabular}

January, with an annual average of $28{ }^{\circ} \mathrm{C}$ based on the same observation period.

Downstream of Malanville is the Kainji lake which resulted from a multipurpose dam project installed in 1968 (Fig. 1). The purposes of the reservoir include power generation, progressive development of navigation, flood control in the Niger valley, and estimated fishery production of over 10,000 tons annually. The reservoir has a total storage volume of $15 \mathrm{~km}^{3}$ and a surface area of $1,270 \mathrm{~km}^{2}$ at maximum water surface elevation (Jimoh 2008). Kainji dam has eight hydropower plants with a total installed capacity of 760 MW (Jimoh 2008) and supplies $12 \%$ of the total electricity of Nigeria (Mohammed et al. 2013). Since 1990, more frequent extreme events in inflow to the reservoir have led to increased downstream spill discharge, sometimes resulting in floods downstream. Such aggravated flooding was witnessed in some downstream communities in 1997 and 1998 when properties worth over 3 million USD were destroyed (Salami and Sule 2010).

Data collection

\section{Hydro-climatic data}

To analyze shifts in the regimes of hydro-climatic variables in the study areas, we collected historical records of precipitation and river discharge. At Malanville, daily precipitation was available for the period 1950-2010 and daily river discharge from 1952 to 2010 . At Kainji, we evaluated daily precipitation from 1972 to 2010. Daily hydrological records (reservoir level and outflow) of Kainji Lake were obtained from Kainji Hydro-Electric Power Authority for a 10 -year period (the maximum length of records that was made available) from 2001 to 2010.

\section{Socioeconomic data}

A survey with a questionnaire addressing climate trends and adaptation mechanisms (Table 1) was used to investigate the perception of climate variability/change and adaptation of the local population to those changes. From September to November, 2012, a total of 239 questionnaires were administered through a personal oral interview. The respondents were from thirty different communities (Fig. 1), fourteen along the Niger and its tributaries (Sota, Alibori and Mekrou) in the Malanville area and sixteen in the Kainji Lake area. A total of 120 and 119 respondents were, respectively, interviewed in both areas. The respondents were randomly selected from the communities, with the community sample weighted with population size. The majority of respondents in Malanville are involved in multiple farming practices; $61 \%$ are involved in crop farming, $21 \%$ are into livestock production, $11 \%$ are involved in fish farming, and the remaining $7 \%$ are engaged in other activities. At Kainji, $27 \%$ of respondents are located downstream of the Kainji dam, while $73 \%$ were upstream of the dam.

In line with the methodology of Tambo and Abdoulaye (2012), respondents were initially asked whether they had heard or read about climate change in order to ascertain their level of awareness. This was followed by questions regarding their perceptions of changes in rainfall and river discharge in the area over the past 20 years, their perceived impacts of climate change on water resources and adaptation mechanisms (Table 1). Data obtained from the questionnaires were analyzed and compared with the respective hydro-climatic observations.

\section{Data analysis}

To detect significant shifts in hydroclimatology (the annual total rainfall, number of rainy days - a rainy day was defined as a day when total rainfall was $>0.1 \mathrm{~mm}$ - and average discharge at Malanville), we used the regime shift detection definition of Rodionov and Overland (2005).

A regime shift occurs when a statistically significant difference exists between the mean value of the variable before and after a certain point in time based on the $t$ test. For each observation $x$ in a time series, a test is performed to determine whether it represents a statistically significant deviation from the mean value of the current regime $\left(x_{\text {mean }}^{\text {curr }}\right)$. According to the $t$ test, the difference (diff) between $x_{\text {mean }}^{\text {curr }}$ and mean value of the new regime $\left(x_{\text {mean }}^{\text {new }}\right)$ will be statistically significant at the level $p$ if it satisfies the condition: 


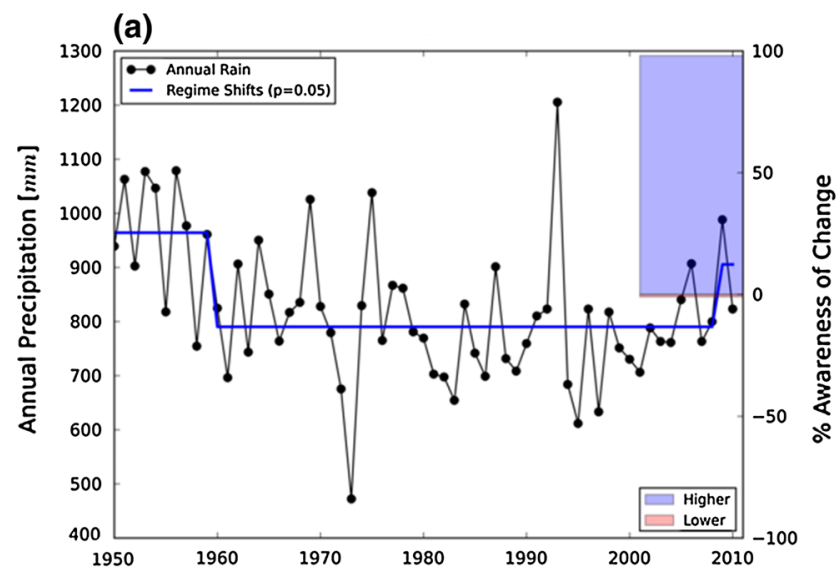

(c)

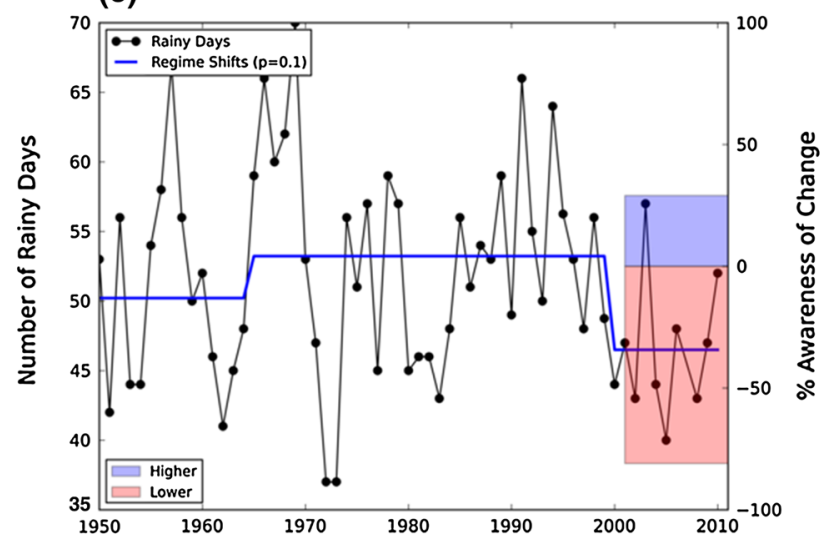

Fig. 2 Observed and local perceptions of rainfall trends and number of rainy days. a annual rainfall at Malanville $\mathbf{b}$ annual rainfall at Kainji $\mathbf{c}$ number of rainy days at Malanville $\mathbf{d}$ number of rainy days at

$\operatorname{diff}=\left|x_{\text {mean }}^{\text {new }}-x_{\text {mean }}^{\text {curr }}\right|=t \sqrt{\left(2 s_{\mathrm{t}}^{2}\right) / l}$

where $t$ is the value of $t$-distribution with $2 l-2$ degrees of freedom, and $l$ is the number of years. In this study, three probability levels $p(0.01,0.05$ and 0.10$)$ were tested to assess the magnitude of the shifts. It was assumed here that variances for both regimes were the same and equal to the average variance for running $l$-year intervals in the time series $\left(x_{\mathrm{i}}\right)$. We also analyzed intra-decadal variations of the Kainji reservoir release and water level for 3-year intervals between 2002 and 2010.

\section{Results}

Climate trends and local perceptions

A regime shift toward a decrease in total annual rainfall $(p=0.05)$ was observed at Malanville from 1959 until 2008 when a significant increase $(p=0.05)$ was observed (Fig. 2a). The same pattern of a significant rainfall increase

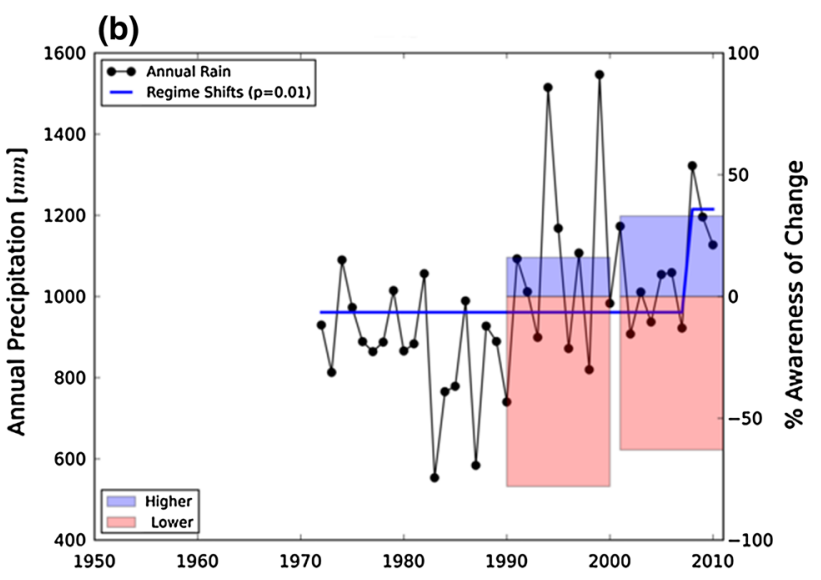

(d)

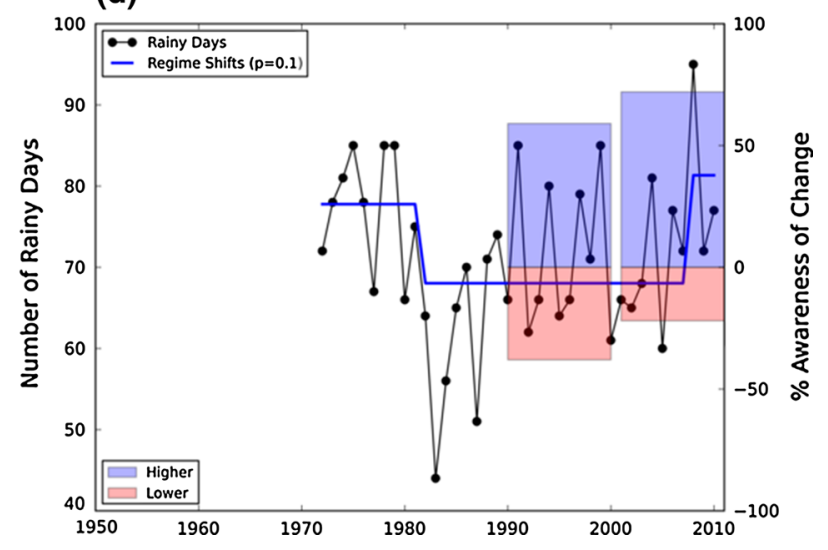

Kainji; Boxes (Kainji, left downstream and right upstream) show percentage of respondents stating higher (blue) or lower (red) conditions

$(p=0.01)$ in 2008 was prominent in Kainji (Fig. 2b). The claim of increasing rainfall by $97 \%$ of respondents in Malanville was in line with these observations (Fig. 2a). At Kainji, on the other hand, $63 \%$ of upstream and $78 \%$ of downstream respondents believed that they witnessed less rainfall compared with past decades (Fig. 2b).

Lower rainfall frequency was reported in Malanville which was in line with observed trend of the decreasing number of rainy days (Fig. 2c). An upward shift in number of rainy days $(p=0.1)$ was observed at Malanville between 1965 and 2000 when there was a downward shift in regime of rainy days (Fig. 2c). Higher rainfall frequency was reported by 59 and $72 \%$ of the downstream and upstream respondents in Kainji which was also in line with recent observed trend of increasing number of rainy days (Fig. 2d). A downward shift in number of rainy days ( $p=0.1$ ) was observed between 1982 and 2007, a period after which an upward shift is observed (Fig. 2d).

In Malanville, $87 \%$ of the respondents were aware of climate change and its impacts on water resources (Table 2); $78 \%$ reported that it led to increase in river 
Table 2 Perceptions of climate and socioeconomic changes in Malanville and Kainji

\begin{tabular}{|c|c|c|c|c|}
\hline \multirow{2}{*}{$\begin{array}{l}\text { Variable } \\
\text { Groups }\end{array}$} & \multirow[t]{2}{*}{ Variables } & \multirow{2}{*}{$\begin{array}{l}\text { Malanville } \\
(\%)\end{array}$} & \multicolumn{2}{|l|}{ Kainji (\%) } \\
\hline & & & Downstream & Upstream \\
\hline \multirow{2}{*}{$\begin{array}{l}\text { Climate } \\
\text { change } \\
\text { awareness }\end{array}$} & Yes & 87 & 97 & 88 \\
\hline & No & 13 & 3 & 12 \\
\hline \multirow{3}{*}{$\begin{array}{l}\text { Effects of } \\
\text { climate } \\
\text { change on } \\
\text { water } \\
\text { resources }\end{array}$} & +Flow & 78 & 94 & 86 \\
\hline & + Flood & 82 & 91 & 43 \\
\hline & $\begin{array}{c}+ \text { Water } \\
\text { stress }\end{array}$ & 63 & 69 & 51 \\
\hline \multirow{3}{*}{$\begin{array}{l}\text { Determinant } \\
\text { of } \\
\text { economic } \\
\text { activities }\end{array}$} & Rainfall & 98 & 100 & 98 \\
\hline & Land & 81 & 63 & 48 \\
\hline & $\begin{array}{l}\text { Alternative } \\
\text { water } \\
\text { sources }\end{array}$ & 59 & 81 & 29 \\
\hline
\end{tabular}

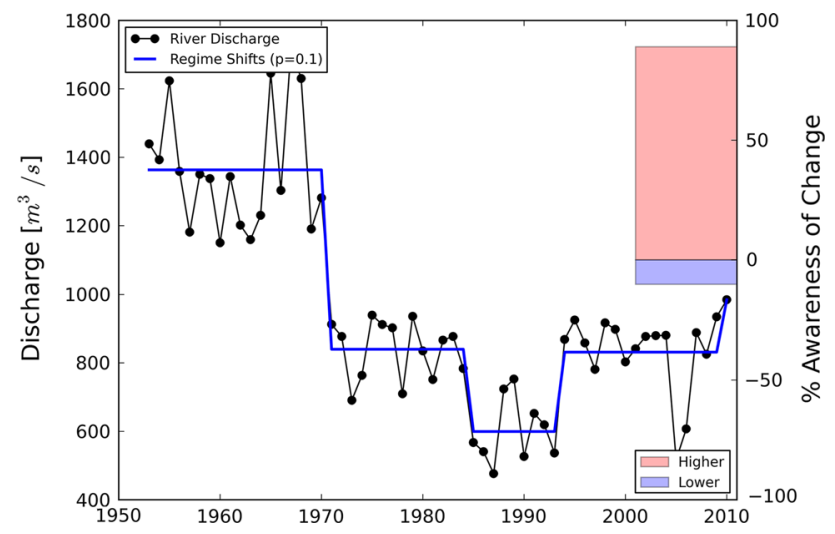

Fig. 3 River discharge trend and flood perception in Malanville; Boxes show percentage of respondents stating higher (red) or lower (blue) conditions

discharge, $82 \%$ highlighted greater floods, and $63 \%$ revealed that there was more water stress compared with the past. At Kainji, perception of climate change was dependent on location relative to Kainji dam, 97 and $88 \%$ downstream and upstream respondents disclosed that they were aware of climate change and its influence in the region (Table 2). Ninety-four and eighty-six percent of the respondents from downstream and upstream said that climate change led to high river flow/discharge; flood and water stress was dominant downstream Kainji dam as disclosed by 91 and $69 \%$, respectively.

A vast majority $(90 \%)$ of the respondents in Malanville disclosed that higher river flow led to greater floods in the area (Fig. 3). Observations revealed that the Niger river discharge at Malanville experienced a downward shift $(p=0.1)$ in 1971 and 1985; however, increasing discharge $(p=0.1)$ was observed from 1994 until 2010 (Fig. 3). At

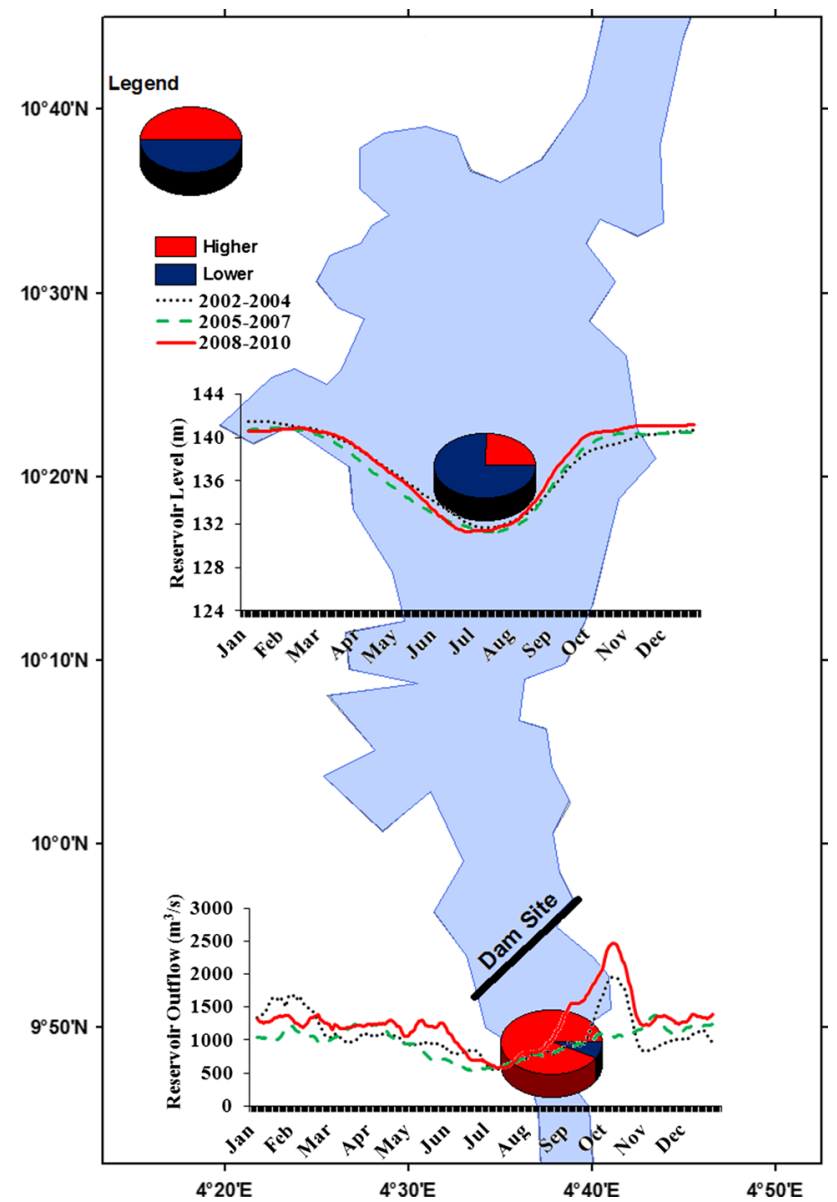

Fig. 4 River discharge trend and flood perception in Kainji; pies show percentage of respondents stating higher (red) or lower (blue) conditions, while lines are 11 days moving averages of the time slices

Kainji, greater flooding was dominant downstream of the dam as disclosed by $84 \%$ of the respondents; against $19 \%$ upstream respondents (Fig. 4). Dynamics of the reservoir level of Kainji dam (Fig. 4) showed slight fluctuations in upstream water level in the three evaluated time slices. Downstream outflow from the lake showed a rapid increase from August to November in 2008-2010 which was not observed in other evaluated periods.

At Malanvile, $98 \%$ of the respondents disclosed rainfall as a key climate variable that affected their activities, $81 \%$ agreed on land (soil and water) availability as another main factor which determined their production (Table 2). The importance of alternative water supply for agriculture (irrigation/animal watering) and domestic purposes was revealed by $59 \%$ (Table 2). In Kainji, above $98 \%$ on both sides of the dam revealed rainfall as a key climate variable that affected their activities while $63 \%$ downstream and $48 \%$ upstream identified land (soil and water) availability as another main factor which determined the extent of their production. Eighty-one percent of downstream and twenty- 
Table 3 Adaptations to climate change in Malanville and Kainji

\begin{tabular}{lllll}
\hline Variable & Response & $\begin{array}{l}\text { Malanville } \\
(\%)\end{array}$ & Kainji (\%) & \\
\cline { 4 - 5 } & & & Downstream & Upstream \\
\hline $\begin{array}{l}\text { Deployment of } \\
\text { adaptation }\end{array}$ & Yes & 52 & 75 & 38 \\
methods & No & 48 & 25 & 62 \\
Early warning & Yes & 43 & 47 & 53 \\
systems & No & 57 & 53 & 47 \\
NGOs & Yes & 31 & 0 & 7 \\
& No & 49 & 81 & 84 \\
& I do not & 20 & 19 & 9 \\
Recovery aid & know & & & \\
& Yes & 39 & 6 & 7 \\
Collaboration & No & 61 & 94 & 93 \\
& Yes & 25 & 9 & 10 \\
& No & 42 & 28 & 72 \\
& I do not & 33 & 63 & 17 \\
& know & & & \\
\hline
\end{tabular}

nine percent of upstream respondents disclosed the availability of alternative water supply as a variable factor of economic production.

\section{Adaptation mechanisms}

Adaptation methods employed in the two locations are indicated in Table 3 and Fig. 5. Although most of the respondents claimed that they had perceived at least one change in climatic attributes, $52 \%$ of Malanville, $38 \%$ of upstream (Kainji) and $75 \%$ of downstream (Kainji) respondents had adaptive measures (Table 3). Investigation of adopted soil and water conservation mechanisms in Malanville (Fig. 5a) indicated that above $86 \%$ respondents deployed local drinking water treatment such as water sediment coagulation, $44 \%$ engage in measures of flood control, $58 \%$ in agroforestry (mixed cultivation of crops and economic trees), $52 \%$ in measures of reclamation of flooded areas (land reclamation) and $48 \%$ adopted soil amendments with fertilizers.

At Kanji, there were differences in adaptation measures depending on the location (upstream or downstream) of the dam (Fig. 5a). Seventy-five percent of respondents' downstream embraced flood control as valid means of adaptation while only $18 \%$ of respondents' upstream used flood control. Fifty and twenty-six percent of respondents' downstream and upstream used water storage; 75 and $43 \%$ respondents' downstream and upstream deployed treatment of water, respectively. Agroforestry was practiced by $50 \%$ downstream and $78 \%$ upstream, soil amendments were generally low (28\% downstream and $32 \%$ upstream), and land reclamation was not a common practice in the area.

Malanville residents responded to declining rainfall by seeking alternative water supply (for domestic use, irrigation and animal watering) from rivers, lakes and small wells (Fig. 5b). They also used adapted crop varieties or moved into other economic activities (diversification). Other methods are the reduction of the cultivated area, or the use of small ponds. Some farmers $(48 \%$ ) abandoned their production. The residents of Kainji responded to (a)

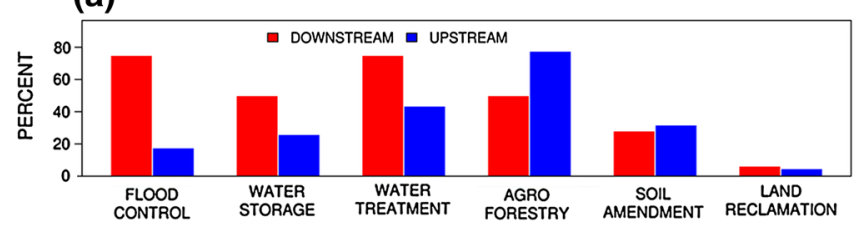

(b)

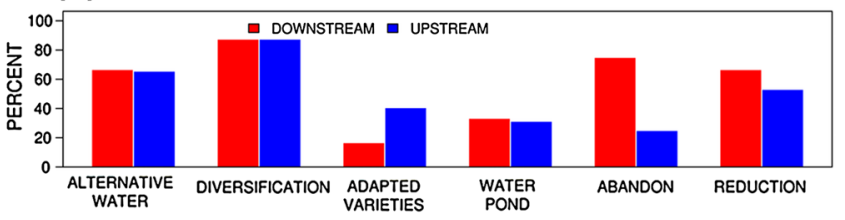

(c)

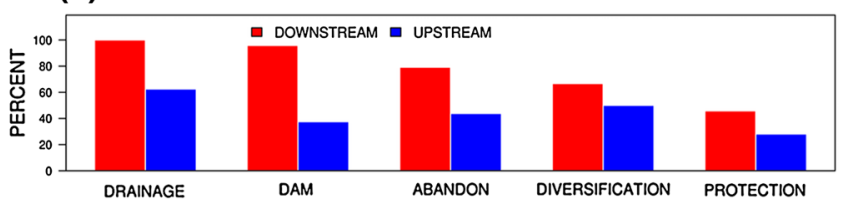

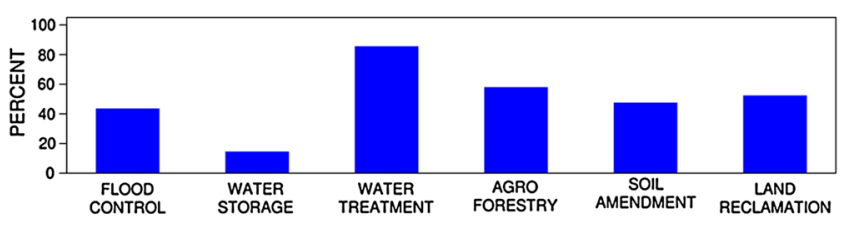
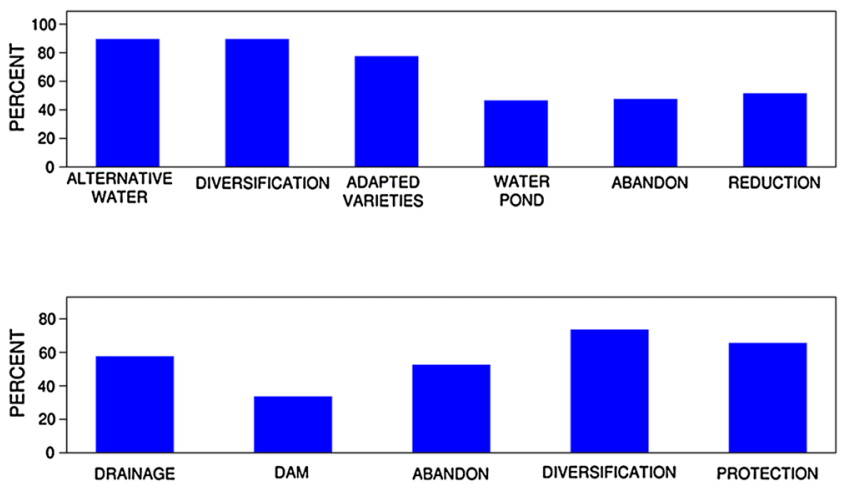

Fig. 5 Adaptation mechanisms in Kainji (left) and Malanville (right) a General soil and water conservation mechanisms b Declining rainfall adaptations c Flood adaptations 
decline in rainfall by seeking alternative water sources, diversification into non agricultural activities (such as selling water to other households) and reduction of the farm size (Fig. 5b). The use of adapted varieties and small water ponds was not embraced in Kainji, and abandoning of farmlands was reported downstream by $75 \%$ of the respondents. In order to adapt to extreme flood events in Malanville, more than $70 \%$ of respondents diversify into other sources of income for the duration of the flood (Fig. 5c). Other deployed methods are the construction of dam/dikes, drainage, abandoning of flooded farm lands and protection of exploited areas (such as reinforcement of open water ponds by fish farmers) (Fig. 5c). At Kainji, more than $90 \%$ of the respondents' downstream used drainage and small dam/dikes for flood protection while only 63 and $38 \%$ of upstream respondents used such methods (Fig. 5c). Other embraced flood adaptation mechanisms in Kainji included abandoning of production land and diversification into other sources of income. Protections of properties during floods were not prominent in the area.

The level of institutional adaptations investigated in Malanville revealed that access to early warning systems of extreme events is low in the area (43\%). Access to governmental recovery aid was experienced by $39 \%$ of respondents while activities of non-governmental organizations (NGOs) such as raising the awareness on impacts of climate change and capacity building on methods of resilience against floods were witnessed by $31 \%$ of the respondents (Table 3). Inter-communal collaborations in combating impacts of floods on the communities were also reported to be low (Table 3). Activities of NGOs in Kainji were also low as highlighted by none of downstream and $7 \%$ of upstream respondents. Governmental recovery aid was given to 6 and $7 \%$ downstream and upstream respondents while early warning systems were available to 47 and $53 \%$ respondents at the downstream and upstream, respectively (Table 3). Inter-communal collaborations were also low in Kainji (Table 3).

\section{Discussion}

The observed significant decrease $(p=0.05)$ in rainfall at Malanville since 1970 was the result of a $150 \mathrm{~km}$ downward shift in rainfall isohyets which resulted into rainfall deficit of 180-200 mm all over West Africa from 1970-1990 compared to 1951-1969 (Lebel and Ali 2009). The observed increase in rainfall from 1990 to 2010 in Malanville $(p=0.05)$ and Kainji $(p=0.01)$ was due to regional increasing rainfall pattern in the eastern part of the Sahel (Amogu et al. 2010). This phenomenon was accrued with higher rainfall in July compared with 1970-1989 dry periods (Lebel and Ali 2009). The observed significant increase in discharge since 2007/2008 in Kainji and Malanville $(p=0.1)$ has increased the flooding risk, and in combination with increasing population pressure led to greater economic implications of flooding in the two study sites. This is in line with the observations of Sarr (2012) who reported an increase in annual flood events in 2007, 2008 and 2009 compared with annual floods from 1966 to 1980 in West Africa. Water levels in Kainji Lake showed less variability as a result of the reservoir operation to maintain a high water level for hydropower production. However, during high inflow, excess water is discharged through the spill gates and can result in severe flooding downstream.

There was a close agreement between local perceptions and observed trends in the two locations especially in the most recent years. Higher rainfall was declared by respondents from Malanville which was in line with analysis of regime shifts. Decreasing and increasing number of rainy days prominent in Malanville and Kainji was in line with local perceptions of lower and higher frequency of rainfall in the two sites. The strong consistency between the observations and the local perceptions was also observed by Kalanda-Joshua et al. (2011) in Malawi where local perceptions adequately capture recent key climatic events. Mertz et al. (2009) made similar observations in Eastern Saloum (Senegal) where farmers were strongly aware of climate and had clear opinions on changes. Similar matching between local perceptions and observed trends was reported in Ghana by Kemausuor et al. (2011). These studies also emphasized that local perceptions of climatic changes can be used to complement climatic studies and reduce effects of uncertain regional observations. Based on studies in Benin, Cuni-Sanchez et al. (2012) suggested the use of local perceptions for complementing climatic studies in the absence of reliable records. Local observations could be used in determining data transferability to poorly gauged basins. They can also give a pointer to overlooked aspects and thus assist in formulating viable research questions (Byg and Salick 2009) along with assistance in coordination of intervention efforts.

However, the discrepancies between perceptions upstream and downstream of the dam highlighted some important sources of bias in local perceptions when compared with climate observations. Higher percentage of respondents' upstream the Kainji dam perceived the recently increasing rainfall trend $(p=0.01)$ since 2008 (Fig. 2) against their downstream counterparts. Rainfall station located at the upstream, tip of the Kainji lake (Fig. 1), might not effectively capture rainfall trends in far away communities. Similar observations were made in Ethiopia by Meze-hausken (2004) where available monthly 
rainfall records hide changes in seasonal rainfall patterns and led to some deviation between observations and local perceptions. Morestill, the operation of the dam separates the effects of river flow and has lead to different adaptation measures upstream and downstream. This is relevant for designing adequate interventions for individual communities around Kainji rather than treating the area as a single unit. This is in line with the observations of Byg and Salick (2009), who reported that perceptions give fine scale information, which are shaped by local geographical region, climatic differences and subsistence activities. Reported higher water stress across the communities despite an increase in rainfall and discharge may be due to effects of population pressure and confirm previous findings that population growth will place severe constraints on water availability for development in Africa (Falkenmark 1990). A well-engineered efficient water use system might be advantageous in mitigating water-related constraints on development in the region (Vörösmarty and Douglas 2005).

Despite the enormous climate change challenges in the study area and the impacts of flood and drought on the economic activities of the local population, only about $50 \%$ of the respondents deployed adaptation measures (Table 3). This can be generally attributed to inadequate and poorly coordinated governmental and non-governmental interventions. Involvement of local populations in designing and implementing these interventions could reduce effects of hydro-climatic changes and improve adaptive capacity of the region (Sissoko et al. 2010). Higher adaptation of residents' downstream Kainji dam was due to flooding witnessed as a result of spill discharge from the reservoir and shows that people that experiences frequent flooding express more concern and greater willingness to take action against climate change (Spence et al. 2011). Respondents embraced the use of local level water treatment as a result of inadequate drinking water supplies which keep the communities on high alert of water borne disease like cholera that is rampant in the region (Okeke et al. 2001). Other methods of climate change adaptations include flood control which was disclosed to be highly important for Malanville and residents' downstream of the Kainji dam.

\section{Conclusions}

Our study highlights the importance of indigenous knowledge in climate change assessments and adaptations. We evaluated the consistency of local knowledge and responses to climate change with observations of hydroclimatic variables in two Niger basin settlements. The two settlements (Malanville and Kainji) along the Niger river have gone through significant variations in precipitation and river discharge which has different impacts at the local scale. Perceptions of climate indicators were highly consistent with observations demonstrating the value of local knowledge. Indigenous people that carry large share of climate change effects are typically excluded from official climate interventions (Green and Raygorodetsky 2010), but the integration of their knowledge could reduce effects of deteriorating hydro-climatic observations and enhance sustainable adaptations. Local populations gave important information that could improve our understanding of climate trends in data scarce regions. However, impacts of these climatic changes were dependent on environmental factors (such as the location relative to a dam) and how this is captured in local perceptions depends on people's memory capability in recalling recent events. These need to be taken into account when evaluating and using local people's knowledge. Further research should aim at unveiling methods that could be used to maximize exploration of local intelligence on climate change and to help develop locally targeted sustainable adaptation measures.

Acknowledgments This study was funded by the German Ministry of Education and Research (BMBF) through the West African Science Service Center on Climate Change and Adapted Land Use (WASCAL; www.wascal.org) that supports the Graduate Research Program Climate Change and Water Resources at the University of Abomey-Calavi. We thank the Kainji Hydro-Electric Power Authority, the Agence pour la Securite de la Navigation Aerienne en Afrique et a Madagascar (ASECNA) and the Benin Hydrological Service for providing the hydro-meteorological data for Kainji and Malanville. We thank the two anonymous reviewers whose comments have helped in improving the quality of the manuscript.

Conflict of interest The authors declare no conflict of interest.

Open Access This article is distributed under the terms of the Creative Commons Attribution License which permits any use, distribution, and reproduction in any medium, provided the original author(s) and the source are credited.

\section{Refrences}

Ali A, Lebel T (2009) The Sahelian standardized rainfall index revisited. Int J Climatol. doi:10.1002/joc

Amogu O, Descroix L, Yéro KS et al (2010) Increasing river flows in the Sahel? Water 2:170-199. doi:10.3390/w2020170

Ben Mohamed A, Van Duivenbooden N, Abdoussallam S (2002) Impact of climate change on agricultural production in the Sahel-Part 1. Methodological approach and case study for millet in Niger. Clim Change 54:327-348. doi:10.1023/A: 1016189605188

Biasutti M, Giannini A (2006) Robust Sahel drying in response to late 20th century forcings. Geophys Res Lett. doi:10.1029/ 2006GL026067

Byg A, Salick J (2009) Local perspectives on a global phenomenonclimate change in Eastern Tibetan villages. Glob Environ Chang 19:156-166 
Chappell A, Agnew CT (2008) How certain is desiccation in west African Sahel rainfall (1930-1990)? J Geophys Res. doi:10. 1029/2007JD009233

Cuni-Sanchez A, Fandohan B, Assogbadjo AE, Sinsin B (2012) A countrywide multi-ethnic assessment of local communities' perception of climate change in Benin (West Africa). Clim Dev 4:114-128. doi:10.1080/17565529.2012.728126

Dai A, Lamb PJ, Trenberth KE et al (2004) The recent Sahel drought is real. Int J Climatol 24:1323-1331. doi:10.1002/joc.1083

Descroix L, Mahé G, Lebel T et al (2009) Spatio-temporal variability of hydrological regimes around the boundaries between Sahelian and Sudanian areas of West Africa: a synthesis. J Hydrol 375:90-102. doi:10.1016/j.jhydrol.2008.12.012

Diallo I, Sylla MB, Giorgi F et al (2012) Multimodel GCM-RCM ensemble-based projections of temperature and precipitation over West Africa for the early 21st century. Int J Geophys 2012:1-19. doi:10.1155/2012/972896

Douville H, Salas-Mélia D, Tyteca S (2006) On the tropical origin of uncertainties in the global land precipitation response to global warming. Clim Dyn 26:367-385. doi:10.1007/s00382-005-0088-2

Druyan LM (2011) Studies of 21st-century precipitation trends over West Africa. Int J Climatol 31:1415-1424. doi:10.1002/joc.2180

Falkenmark M (1990) Rapid population growth and water scarcity: the predicament of tomorrows Africa. Popul Dev Rev 81-94

Fosu-Mensah BY, Vlek PLG, MacCarthy DS (2012) Farmers' perception and adaptation to climate change: a case study of Sekyedumase district in Ghana. Environ Dev Sustain 14:495-505

Giannini A, Biasutti M, Verstraete MM (2008) A climate modelbased review of drought in the Sahel: desertification, the regreening and climate change. Glob Planet Change 64:119-128. doi:10.1016/j.gloplacha.2008.05.004

Green D, Raygorodetsky G (2010) Indigenous knowledge of a changing climate. Clim Change 100:239-242. doi:10.1007/ s10584-010-9804-y

Hulme M (2001) Climatic perspectives on Sahelian desiccation: 1973-1998. Glob Environ Chang 11:19-29

Institut National de la Statistique et de l'analyse Economique (INSAE) (2013) Resultats provisoires du rgph4. http://www.insae-bj.org/ recensement-population.html. Accessed 17 Aug 2014

IPCC (2014) Summary for policymakers. In: Climate change 2014: impacts, adaptation, and vulnerability. Part A: global and sectoral aspects. Contribution of working group II to the fifth assessment report of the intergovernmental panel on climate change. In: Field CB, Barros VR, Dokken DJ, Mach KJ, Mastrandrea MD, Bilir TE, Chatterjee M, Ebi KL, Estrada YO, Genova RC, Girma B, Kissel ES, Levy AN, MacCracken S, Mastrandrea PR, and White LL (eds). Cambridge University Press, Cambridge, United Kingdom and New York, NY, USA, p 26

Jimoh O (2008) Optimized operation of Kainji reservoir. J Technol $12: 34-42$

Kalanda-Joshua M, Ngongondo C, Chipeta L, Mpembeka F (2011) Integrating indigenous knowledge with conventional science: enhancing localised climate and weather forecasts in Nessa, Mulanje, Malawi. Phys Chem Earth, Parts A/B/C 36:996-1003. doi:10.1016/j.pce.2011.08.001

Kemausuor F, Dwamena E, Bart-plange A, Kyei-baffour N (2011) Farmers' perception of climate change in the ejura-sekyedumase district of Ghana. J Agric Biol Sci 6:26-38

L'Hote Y, Mahe G, Some B, Triboulet JP (2002) Analysis of a Sahelian annual rainfall index from 1896 to 2000; the drought continues. Hydrol Sci J 47:563-572. doi:10.1080/ 02626660209492960

Le Barbé L, Lebel T (1997) Rainfall climatology of the HAPEXSahel region during the years 1950-1990. J Hydrol 189:43-73

Le Barbé L, Lebel T, Tapsoba D (2002) Rainfall variability in West Africa during the years 1950-90. J Clim 15(2):187-202
Lebel T, Ali A (2009) Recent trends in the central and Western Sahel rainfall regime (1990-2007). J Hydrol 375:52-64. doi:10.1016/j. jhydrol.2008.11.030

Mahe P, Servat et al (2005) The impact of land use change on soil water holding capacity and river flow modelling in the Nakambe River, Burkina-Faso. J Hydrol 300:33-43. doi:10.1016/j.jhydrol. 2004.04.028

Mertz O, Mbow C, Reenberg A, Diouf A (2009) Farmers' perceptions of climate change and agricultural adaptation strategies in rural Sahel. Environ Manage 43:804-816. doi:10.1007/s00267-0089197-0

Mertz O, Mbow C, Reenberg A et al (2011) Adaptation strategies and climate vulnerability in the Sudano-Sahelian region of West Africa. Atmos Sci Lett 12:104-108. doi:10.1002/asl.314

Meze-Hausken E (2004) Contrasting climate variability and meteorological drought with perceived drought and climate change in northern Ethiopia. Clim Res 27:19-31

Mohammed YS, Mustafa MW, Bashir N, Mokhtar AS (2013) Renewable energy resources for distributed power generation in Nigeria : a review of the potential. Renew Sustain Energy Rev 22:257-268. doi:10.1016/j.rser.2013.01.020

Ogilvie A, Mahéé G, Ward J et al (2010) Water, agriculture and poverty in the Niger river basin. Water Int 35:594-622

Okeke IN, Abudu AB, Lamikanra A (2001) Microbiological investigation of an outbreak of acute gastroenteritis in Niger state, Nigeria. Clin Microbiol Infect 7:514-516

Oyebande L, Odunuga S (2010) Climate change impact on water resources at the transboundary level in West Africa: the cases of the Senegal, Niger and Volta basins. Spec Issue Anal Clim Change impacts water Resour Dev Econ successes chall 4:163-172

Ozer P, Erpicum M, Demaree G, Vandiepenbeeck M (2003) DISCUSSION of "Analysis of a Sahelian annual rainfall index from 1896 to 2000; the drought continues" The Sahelian drought may have ended during the 1990s. Hydrol Sci J 48:489-492. doi:10.1623/hysj.48.3.489.45285

Paeth H, Girmes R, Menz G, Hense A (2006) Improving seasonal forecasting in the low latitudes. Mon Weather Rev 134:1859-1879. doi:10.1175/MWR3149.1

Rodionov S, Overland J (2005) Application of a sequential regime shift detection method to the Bering Sea ecosystem. ICES J Mar Sci 62:328-332. doi:10.1016/j.icesjms.2005.01.013

Roudier P, Sultan B, Quirion P, Berg A (2011) The impact of future climate change on West African crop yields: what does the recent literature say? Glob Environ Chang 21:1073-1083. doi:10.1016/j.gloenvcha.2011.04.007

Rummukainen M (2010) State-of-the-art with regional climate models. Wiley Interdiscip Rev Clim Chang 1:82-96. doi:10. $1002 /$ wcc. 8

Salami AW, Sule BF (2010) An overview on reservoir operational impact of Kainji, Jebba and Shiroro Dams on the environment. Paper presented at the one day seminar on reservoir operation. Organized by Federal Ministry of Water Resources, Department Dams \& Reservoir Operations, pp 1-12. https://www.unilorin. edu.ng/publications/salamiaw/. Accessed 10 Nov 2014

Sarr B (2012) Present and future climate change in the semi-arid region of West Africa: a crucial input for practical adaptation in agriculture. Atmos Sci Lett 13:108-112. doi:10.1002/asl.368

Sissoko K, Keulen H, Verhagen J et al (2010) Agriculture, livelihoods and climate change in the West African Sahel. Reg Environ Chang 11:119-125. doi:10.1007/s10113-010-0164-y

Sivakumar MVK (1992) Climate change and implications for agriculture in Niger. Clim Change 20:297-312

Spence A, Poortinga W, Butler C, Pidgeon NF (2011) Perceptions of climate change and willingness to save energy related to flood experience. Nat Clim Chang 1:46-49. doi:10.1038/nclimate1059 
Sylla MB, Giorgi F, Coppola E, Mariotti L (2013) Uncertainties in daily rainfall over Africa: assessment of gridded observation products and evaluation of a regional climate model simulation. Int J Climatol 33:1805-1817. doi:10.1002/joc.3551

Tambo J, Abdoulaye T (2012) Smallholder farmers' perceptions of and adaptations to climate change in the Nigerian savanna. Reg Environ Chang. doi:10.1007/s10113-012-0351-0

Vörösmarty C, Douglas E (2005) Geospatial indicators of emerging water stress: an application to Africa. Ambio 34:230-236
West CT, Roncoli C, Ouattara F (2008) Local perceptions and regional climate trends on the Central Plateau of Burkina Faso. L Degrad Dev 19:289-304

Yabi I, Afouda F (2012) Extreme rainfall years in Benin (West Africa). Quat Int 262:39-43. doi:10.1016/j.quaint.2010.12.010 